INTERNATIONAL JOURNAL OF RESEARCHES IN BIOSCIENCES, AGRICULTURE \& TECHNOLOGY (C) VISHWASHANTI MULTIPURPOSE SOCIETY (Global Peace Multipurpose Society) R. No. MH-659/13(N)

\title{
VARIOUS TYPES OF RUDRAKSHA BEADS, THEIR BENEFITS AND FTIR SPECTRA
}

\author{
Swaroopa Rani N. Gupta \\ Dept of Chemistry Brijlal Biyani Science College Amravati, MS, India \\ swargupta@yahoo.com
}

\begin{abstract}
:
The word rudraksha, originated from two Sanskrit words Rudra \& Aksha, (Rudra means Lord Shiva, Aksha means Eye). The rudraksha bead is the dried fruit of the tree Elaeocarpus Ganitrus. Rudraksha farming is a difficult process due to the slow sprouting from the beads. Depending on the humidity of the soil, it usually takes 1-2 years for a tree to sprout. Rudraksha is grown in subtropical climatic regions with temperature ranges of 25-30 degree centigrade. The tree starts giving fruit after 7 years. A single Rudraksha tree bears beads in all different faces or mukhis at the same time. The higher mukhis or faces are very rare. Most common Rudraksha bead is the five faceted. The environment and location of Rudraksha trees plays a major role in the bead formation and the type of bead formed. Rudraksha beads do possess powerful electromagnetic, paramagnetic and inductive properties. The healing powers of the Rudraksha bead are derived from such properties.

This study attempts to guide the reader between the various types of Rudraksha Beads and their benefits. Paper also deals with FTIR spectra of Rudraksha Bead.

FTIR can be routinely used to identify the functional groups and identification/quality control of raw material/finished products. FTIR spectra of Rudraksha Bead is obtained at room temperature by using an FTIR Spectrophotometer Perkin Elmer - Spectrum RX-IFTIR. The spectra is collected in a range from 450 to $4000 \mathrm{~cm}^{-1}$.

Interpretation of FTIR Spectra of Rudraksha Bead shows presence of various functional groups such as

Alkane- $\mathrm{CH}_{3}-\mathrm{C}$ Methyl, $\mathrm{CH}_{3}-(\mathrm{C}=\mathrm{O}),-\mathrm{CH}_{2}-$ Methylene, $\mathrm{CH}_{2}-(\mathrm{C}=\mathrm{O}),-\mathrm{CH}_{2}-(\mathrm{C} \equiv \mathrm{N}), \stackrel{\mathrm{CH}}{ }$, Ethyl, n-propyl;

Alkene - Vinyl $-\mathrm{CH}=\mathrm{CH}_{2},>\mathrm{C}=\mathrm{CH}_{2}$

Alcohols - Secondary $\mathrm{CH}-\mathrm{OH}$

Acids - Carboxylic acids $\mathrm{COOH}$

Esters - Formates $\mathrm{H}-\mathrm{CO}-\mathrm{O}-\mathrm{R}$, Acetates $-\mathrm{CH}_{2}-\mathrm{CO}-\mathrm{O}-\mathrm{R}$, Propionates $-\mathrm{CH}_{2}-\mathrm{CO}-\mathrm{O}-\mathrm{R}$, Butyrates an up $-\mathrm{CH}_{2}-\mathrm{CO}-\mathrm{O}-\mathrm{R}$,

Acrylates $=\mathrm{CH}-\mathrm{CO}-\mathrm{O}-\mathrm{R}$, Fumarates $=\mathrm{CH}-\mathrm{CO}-\mathrm{O}-\mathrm{R}$, Maleates $=\mathrm{CH}-\mathrm{CO}-\mathrm{O}-\mathrm{R}$, Benzoates, phthalates $\square$-co-O-R;

Aldehydes - Aliphatic Aldehydes $-\mathrm{CH}_{2}-\mathrm{CHO}$;

Ketones - Aliph. Ketones $\mathrm{CH}_{2}-\mathrm{CO}-\mathrm{CH}_{2}$;

Amides - $\mathrm{CO}-\mathrm{NH}_{2}$
\end{abstract}

Anhydrides - Normal anhydrides $\mathrm{C}-\mathrm{CO}-\mathrm{O}-\mathrm{CO}-\mathrm{C}$, Cyclic anhydrides

Key Words: Elaeocarpus Ganitrus, Rudraksha Bead, Mukhi, FTIR Spectra

\section{INTRODUCTION}

The word rudraksha, originated from two Sanskrit words Rudra \& Aksha, (Rudra means Lord Shiva, Aksha means Eye).[1, 2] The rudraksha bead is the dried fruit of the tree Elaeocarpus Ganitrus. Rudraksha farming is a difficult process due to the slow sprouting from the beads. Depending on the humidity of the soil, it usually takes 1-2 years for a tree to sprout. Rudraksha is grown in subtropical climatic regions with temperature ranges of 25 30 degree centigrade. The tree starts giving fruit after 7 years. A single Rudraksha tree bears beads in all different faces or mukhis at the same time. The higher mukhis or faces are very rare. Most common Rudraksha bead is the five faceted. The environment and location of Rudraksha trees plays a major role in the bead formation and the type of bead formed. For example the Himalayan beads seem larger, heavier and more powerful due to the environment they grow in. The seed is produced by several species of large evergreen broadleaved tree in the genus Elaeocarpus, with Elaeocarpus ganitrus being the principal species. The Rudraksha fruit is blue, but turns black when dried. The central hard seed may have 1 to 21 faces. The Rudraksha tree found 
from sea level up to 3000 meters above. The percentage compositions of the gaseous elements present in a Rudraksha was determined by C-H-N Analyzer and by Gas

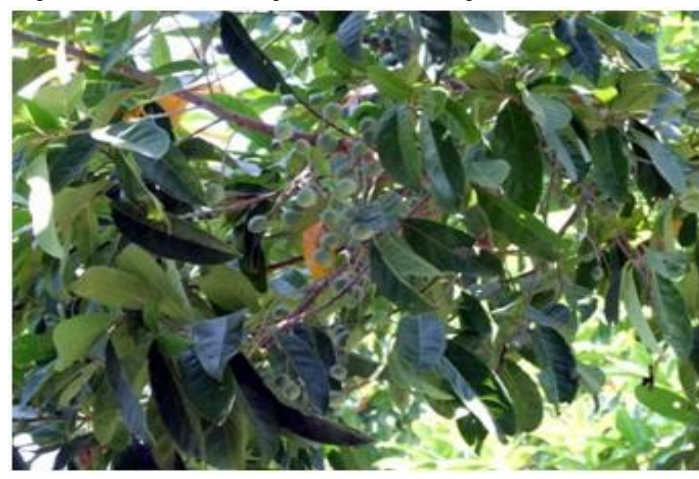

Figure 1. Rudraksha Tree

Rudraksha beads are classified on the basis of the number of mukhis / faces - the clefts and furrows - they have on the surface. Each bead has a different effect, depending on the number of mukhis it has. These are vital from the astrological viewpoint, since it is believed that Rudrakshas of different mukhis please different planets. The scriptures speak of 1 to 38 mukhis, but Rudrakshas of 1 to 13 mukhis are commonly found. 14-21 are rare ones. chromatography. Rudraksha beads contain $50.031 \%$ carbon, $0.95 \%$ nitrogen, $17.897 \%$ hydrogen and $30.53 \%$ oxygen.

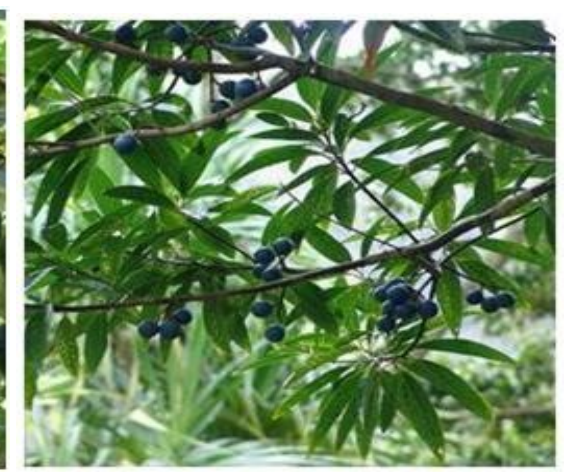

Rudrakshas give several beneficial effects to the wearer and at the same time do not have any negative effects. Hence anyone can wear any Rudraksha. No combination is bad while wearing rudraksha, all combinations are good as rudrakshas dont have any negative effects. Many astrologers have also worked on Rudraksha. They suggest 'Mukhi' based on Birth Rashi and Nakshatra. However one could wear according to the needs / desires to be fulfilled.

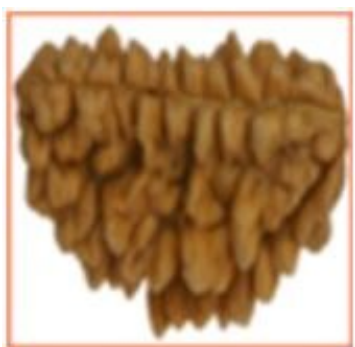

One Faced

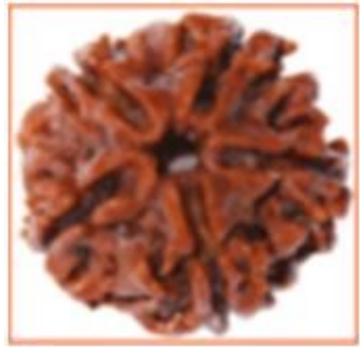

Five Faced

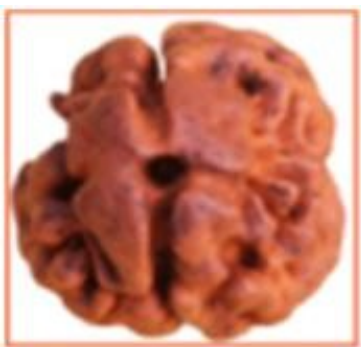

Two Faced

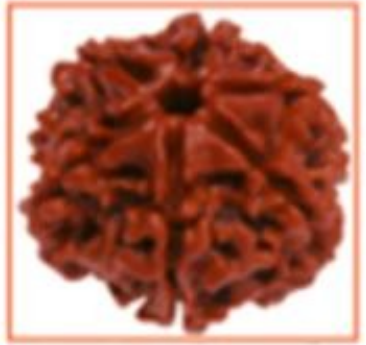

Six Faced

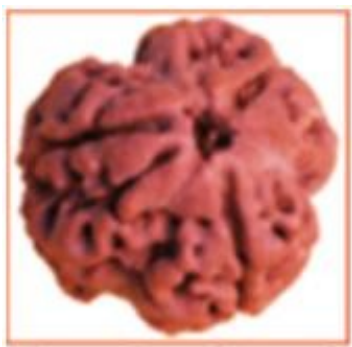

Three Faced

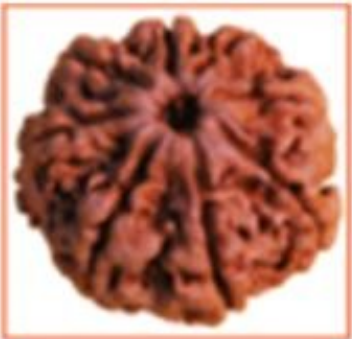

Seven Faced

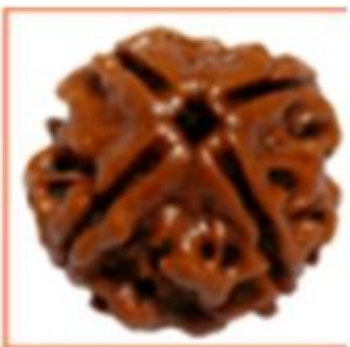

Four Faced

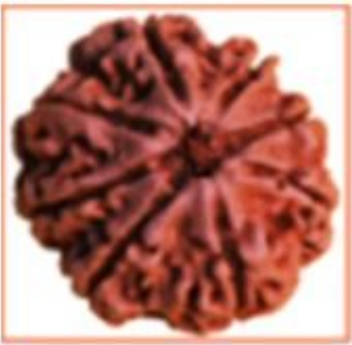

Eight Faced 

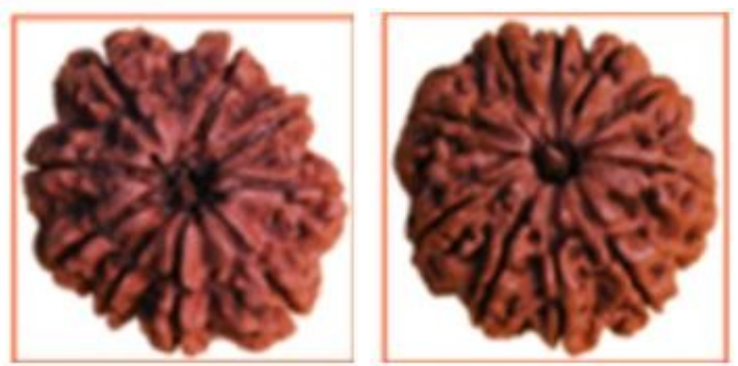

Nine Faced

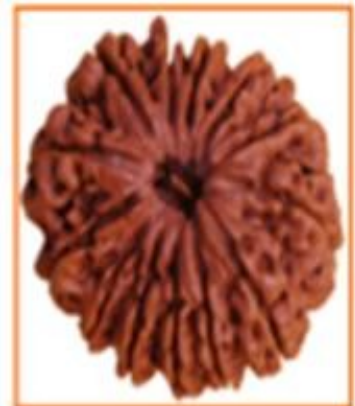

Thirteen Faced

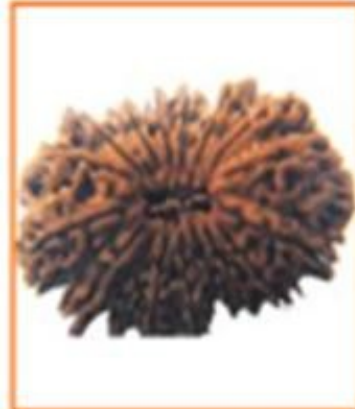

Seventeen Faced

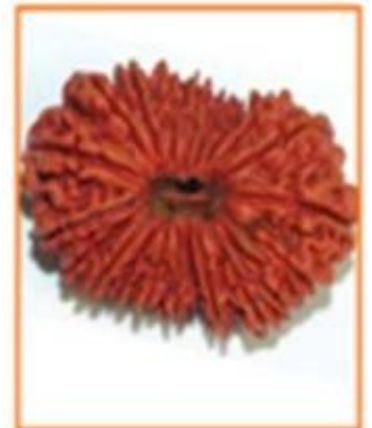

Twenty One Faced
Ten Faced

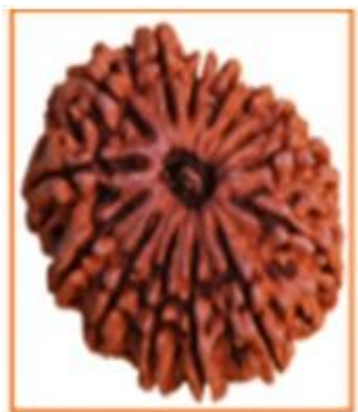

Fourteen Faced

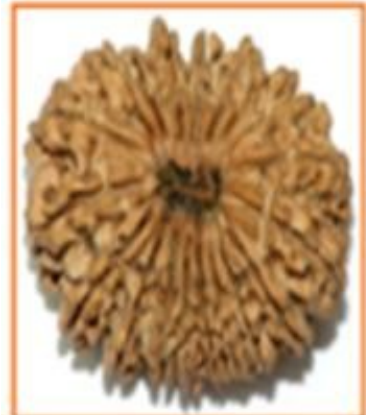

Eighteen Faced

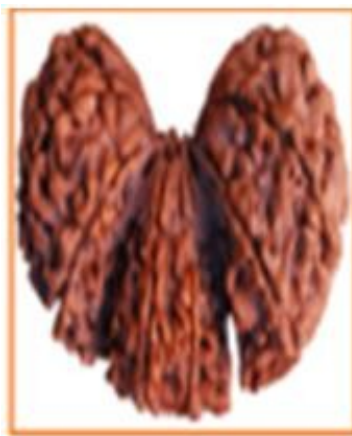

Trijuti

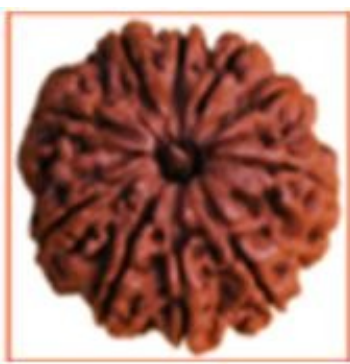

Eleven Faced

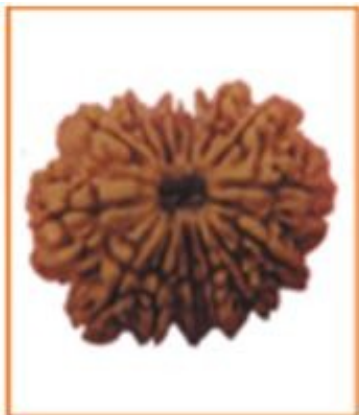

Fifteen Faced

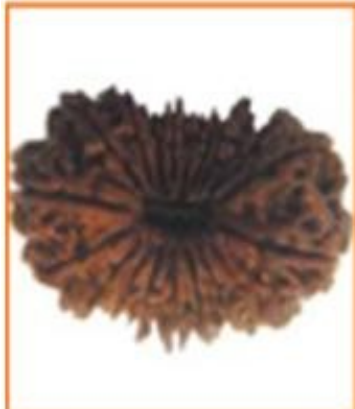

\section{Nineteen Faced}

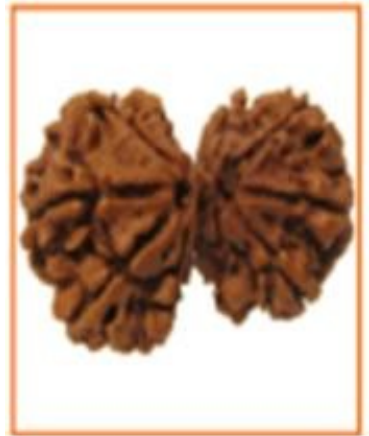

Gauri Shankar

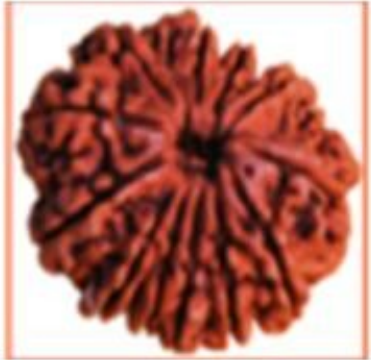

Twelve Faced

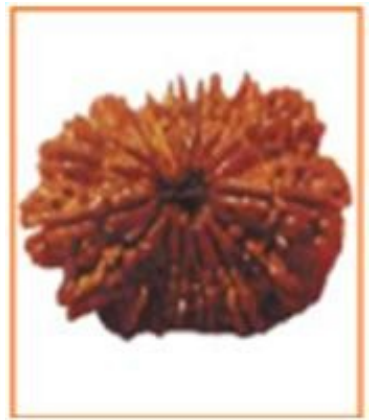

Sixteen Faced

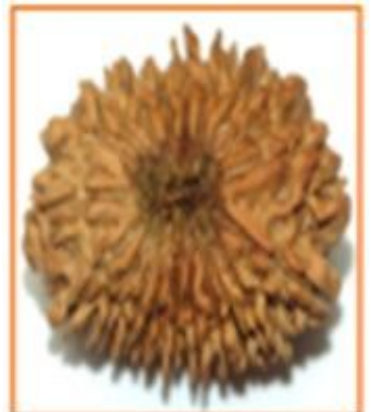

Twenty Faced

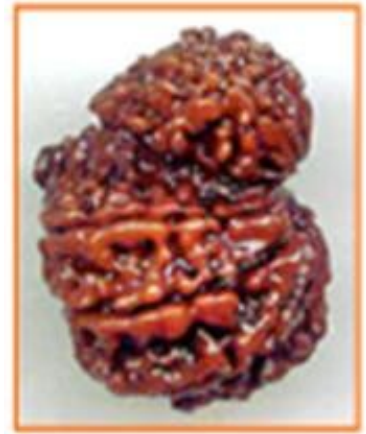

Garbh Gauri

Figure 2. Various types of Rudraksha Beads

As scripted in the ancient scriptures, Rudraksha beads do possess powerful electromagnetic, paramagnetic and inductive properties. The healing powers of the Rudraksha bead are derived from such properties. Blood circulation and heart beats automatically induce a magnetic field around the body and particularly the heart region. Accordingly, a balancing force is exerted on the heart to regulate it if it starts beating above or below normal rates. This action helps to ensure ideal blood circulation in the body. Depending upon the polarity and intensity of the 
induced magnetic field, Rudraksha beads transmit subtle electrical and inductive impulses with opposing polarity and intensity. When Rudraksha beads are placed over the heart, they act to stabilize the heart beat. Thus, the stated beneficial effects of the Rudraksha bead have been proved scientifically as well.

According to the Ayurvedic medical system, wearing Rudraksha can have a positive effect on the heart and nerves, and relieve person from stress, anxiety, depression, palpitations and lack of concentration. It is also known for its anti ageing effect, and electromagnetic and inductive properties. People with high blood pressure have been found benefited from the use of Rudraksha seeds.

Elaeocarpus ganitrus grows in the area from the Gangetic plain in the foothills of the Himalayas to Southeast Asia, Nepal, Indonesia, New Guinea to Australia, Guam, and Hawaii.[3] Rudraksha seeds are covered by an outer husk of blue when fully ripe, and for this reason are also known as blueberry beads. The blue colour is not derived from pigment but is structural. It is an evergreen tree that grows quickly. The Rudraksha tree starts bearing fruit in three to four years from germination. As the tree matures, the roots form buttresses, rising up near the trunk and radiating out along the surface of the ground. Rudraksha beads are the material from which mālās are made. The term is used both for the berries themselves and as a term for the type of mālā made from them.[4] In this sense, a Rudraksha is a rosary, used for repetitive prayer (japa), a common aid to worship in Hinduism and other faiths. Rudrakshas are also used for the treatment of various diseases in traditional Indian medicine.[5] A common type has five divisions, and these are considered to be symbolic of the five faces of Shiva. It should only be worn on a black or red string/thread or, rarely, a gold chain.[6, 7] Rudraksha malas have been used by Hindus as rosaries from at least the 10th century [8] for meditation purposes and to sanctify the mind, body and soul.

Biology of rudraksha has been summarized, particularly recent research on the remarkable fruit colour.[9] The brilliant blue of the fruit is caused not by a blue pigment, but by the structure of the cuticle which reflects blue light; thin pieces of skin are green in transmitted light [10]. Blue fruit colour is normally caused by anthocyanins, modified by their association with metals or other flavonoid pigments [11]. However, no such anthocyanins were extractable in acidic methanol in rudraksha fruits,, suggesting that the basis for colour production may well be structural [12]. Three physical methods produce colour in animals: thin film interference, Tyndall scattering, and diffraction [13]. As for iridescent coloration in leaves [14], the basis of the blue iridescence in rudraksha fruits also appears to be thin film interference. The blue coloration of rudraksha fruits is not reduced by immersion in water; if anything the intensity is enhanced. In Selaginella willdenowii and S. uncinata blue leaf iridescence was removed by contact with water, suggesting a location at the surface of the upper epidermis $[15,16]$. In other iridescent-leaved plants, colour was not affected by contact with water, indicating a location beneath the surface $[17$, 18].

This review attempts to guide the reader between the various types of Rudraksha Beads and their benefits. Paper also deals with FTIR spectra of Rudraksha Bead.

\section{METHODOLOGY}

FTIR Spectrophotometer - Perkin Elmer Spectrum RX-IFTIR

FTIR can be routinely used to identify the functional groups and identification/quality control of raw material/finished products. Spectrum RX-I offers fast throughput and rapid access to reliable and dependable IR results. High signal to noise ratio makes FTIR more useful for difficult samples. It has resolution of 1 $\mathrm{cm}^{-1}$ and scan range of $4000 \mathrm{~cm}^{-1}$ to $250 \mathrm{~cm}^{-1}$. In the normal mode around $10 \mathrm{mg}$ sample is required in the form of fine powder. The sample can be analyzed in the form of liquid, solid and thin films also.

Rudraksha Bead is grinded into powder and its FTIR spectra is obtained at room temperature by using an FTIR Spectrophotometer - Perkin Elmer - Spectrum RX-IFTIR. The spectra is collected in a range from 450 to $4000 \mathrm{~cm}^{-1}$. 


\section{RESULTS AND DISCUSSION}

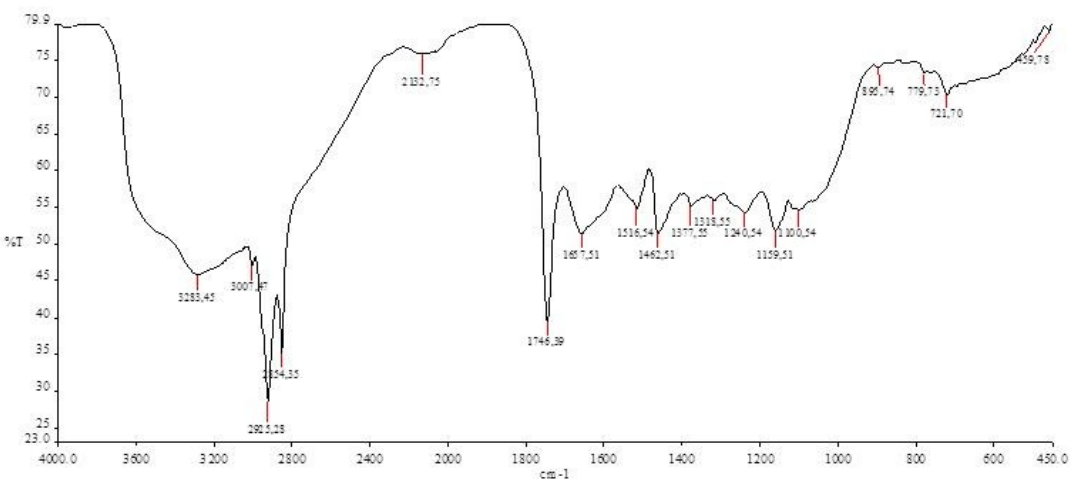

Figure 3. FTIR Spectra of Rudraksha Bead

Figure 3 shows FTIR Spectra of Rudraksha Bead. Interpretation of FTIR Spectra of Rudraksha Bead can be done as follows:

\begin{tabular}{|c|c|c|c|}
\hline S.N. & $\begin{array}{l}\text { Spectral } \\
\text { Region } \\
\text { Wave } \\
\text { number } \\
\text { cm-1 }\end{array}$ & Bond causing absorption & $\begin{array}{l}\text { Pattern and } \\
\text { Intensity of Band }\end{array}$ \\
\hline 1 & 3283.45 & Alcohols - Secondary $\mathrm{CH}-\mathrm{OH}$ & $\begin{array}{l}\text { Broad and Strong } \\
\text { Intensity }\end{array}$ \\
\hline 2 & 3007.47 & - & $\begin{array}{l}\text { Broad and Strong } \\
\text { Intensity }\end{array}$ \\
\hline 3 & 2925.28 & $\begin{array}{l}\text { Alkane }-\mathrm{CH}_{3}-\mathrm{C} \text { Methyl, } \mathrm{CH}_{3}-(\mathrm{C}=\mathrm{O}),-\mathrm{CH}_{2}- \\
\text { Methylene, } \mathrm{CH}_{2}-(\mathrm{C}=\mathrm{O}),-\mathrm{CH}_{2}-(\mathrm{C} \equiv \mathrm{N}),>\mathrm{CH} \text {, } \\
\text { Ethyl, n-propyl; } \\
\text { Alkene - Vinyl }-\mathrm{CH}=\mathrm{CH}_{2},>\mathrm{C}=\mathrm{CH}_{2}\end{array}$ & $\begin{array}{l}\text { Sharp and Strong } \\
\text { Intensity }\end{array}$ \\
\hline 4 & 2854.35 & Alkane $-\mathrm{CH}_{3}-\mathrm{C}$ Methyl, $-\mathrm{CH}_{2}-$ Methylene, $>\mathrm{CH}$ & $\begin{array}{l}\text { Sharp and Strong } \\
\text { Intensity }\end{array}$ \\
\hline 5 & 2132.75 & - & $\begin{array}{l}\text { Broad and Moderate } \\
\text { Intensity }\end{array}$ \\
\hline 6 & 1746.39 & $\begin{array}{l}\text { Esters - Formates } \mathrm{H}-\mathrm{CO}-\mathrm{O}-\mathrm{R} \text {, Acetates }-\mathrm{CH}_{2}-\mathrm{CO}- \\
\mathrm{O}-\mathrm{R} \text {, Propionates }-\mathrm{CH}_{2}-\mathrm{CO}-\mathrm{O}-\mathrm{R}, \mathrm{Butyrates} \text { an up } \\
-\mathrm{CH}_{2}-\mathrm{CO}-\mathrm{O}-\mathrm{R} \text {, Acrylates }=\mathrm{CH}-\mathrm{CO}-\mathrm{O}-\mathrm{R} \text {, Fumarates } \\
=\mathrm{CH}-\mathrm{CO}-\mathrm{O}-\mathrm{R} \text {, Maleates }=\mathrm{CH}-\mathrm{CO}-\mathrm{O}-\mathrm{R} \text {, Benzoates, } \\
\text { phthalates } \bigcirc \text {-co-O-R; } \\
\text { Aldehydes - Aliphatic Aldehydes }-\mathrm{CH}_{2}-\mathrm{CHO} ; \\
\text { Ketones - Aliph. Ketones } \mathrm{CH}_{2}-\mathrm{CO}-\mathrm{CH}_{2} ; \\
\text { Anhydrides - Normal anhydrides } \mathrm{C}-\mathrm{CO}-\mathrm{O}-\mathrm{CO}-\mathrm{C} \text {, } \\
\text { Cyclic anhydrides }\end{array}$ & $\begin{array}{l}\text { Sharp and Strong } \\
\text { Intensity }\end{array}$ \\
\hline 7 & 1657.51 & Amides $-\mathrm{CO}-\mathrm{NH}_{2}$ & $\begin{array}{l}\text { Broad and Strong } \\
\text { Intensity }\end{array}$ \\
\hline 8 & 1516.54 & - & $\begin{array}{l}\text { Broad and Strong } \\
\text { Intensity }\end{array}$ \\
\hline 9 & 1462.51 & - & $\begin{array}{l}\text { Broad and Strong } \\
\text { Intensity }\end{array}$ \\
\hline 10 & 1377.55 & - & $\begin{array}{l}\text { Broad and Strong } \\
\text { Intensity }\end{array}$ \\
\hline 11 & 1318.55 & Acids - Carboxylic acids $\mathrm{COOH}$ & $\begin{array}{l}\text { Broad and Strong } \\
\text { Intensity }\end{array}$ \\
\hline
\end{tabular}




\begin{tabular}{|l|l|l|l|}
12 & 1240.54 & Acids - Carboxylic acids $\mathrm{COOH}$ & $\begin{array}{l}\text { Broad and Strong } \\
\text { Intensity }\end{array}$ \\
\hline 13 & 1159.51 & - & $\begin{array}{l}\text { Broad and Strong } \\
\text { Intensity }\end{array}$ \\
\hline 14 & 1100.54 & - & $\begin{array}{l}\text { Broad and Strong } \\
\text { Intensity }\end{array}$ \\
\hline 15 & 895.74 & Acids - Carboxylic acids COOH & $\begin{array}{l}\text { Broad and Moderate } \\
\text { Intensity }\end{array}$ \\
\hline 16 & 779.73 & - & $\begin{array}{l}\text { Broad and Moderate } \\
\text { Intensity }\end{array}$ \\
\hline 17 & 721.70 & - & $\begin{array}{l}\text { Broad and Moderate } \\
\text { Intensity }\end{array}$ \\
\hline 18 & 459.78 & - & $\begin{array}{l}\text { Broad and Moderate } \\
\text { Intensity }\end{array}$ \\
\hline
\end{tabular}

Interpretation of FTIR Spectra of Rudraksha Bead shows presence of various functional groups such as

Alkane - $\mathrm{CH}_{3}-\mathrm{C}$ Methyl, $\mathrm{CH}_{3}-(\mathrm{C}=\mathrm{O}),-\mathrm{CH}_{2}-$ Methylene, $\mathrm{CH}_{2}-(\mathrm{C}=\mathrm{O}),-\mathrm{CH}_{2}-(\mathrm{C} \equiv \mathrm{N}), \rightarrow \mathrm{CH}, \mathrm{Ethyl}, \mathrm{n}-$ propyl;

Alkene - Vinyl $-\mathrm{CH}=\mathrm{CH}_{2},>\mathrm{C}=\mathrm{CH}_{2}$

Alcohols - Secondary $\mathrm{CH}-\mathrm{OH}$

Acids - Carboxylic acids $\mathrm{COOH}$

Esters - Formates H-CO-O-R, Acetates - $\mathrm{CH}_{2}-\mathrm{CO}-\mathrm{O}-\mathrm{R}$, Propionates $-\mathrm{CH}_{2}-\mathrm{CO}-\mathrm{O}-\mathrm{R}$, Butyrates an up $\mathrm{CH}_{2}-\mathrm{CO}-\mathrm{O}-\mathrm{R}$, Acrylates $=\mathrm{CH}-\mathrm{CO}-\mathrm{O}-\mathrm{R}$, Fumarates $=\mathrm{CH}-\mathrm{CO}-\mathrm{O}-\mathrm{R}$, Maleates $=\mathrm{CH}-\mathrm{CO}-\mathrm{O}-\mathrm{R}$, Benzoates, phthalates $\bigcirc$-CO-O-R;

Aldehydes - Aliphatic Aldehydes $-\mathrm{CH}_{2}-\mathrm{CHO}$;

Ketones - Aliph. Ketones $\mathrm{CH}_{2}-\mathrm{CO}-\mathrm{CH}_{2}$;

Amides $-\mathrm{CO}-\mathrm{NH}_{2}$;

Anhydrides - Normal anhydrides $\mathrm{C}-\mathrm{CO}-\mathrm{O}-\mathrm{CO}-\mathrm{C}$, Cyclic anhydrides

\section{CONCLUSION}

FTIR can be routinely used to identify the functional groups and identification/quality control of raw material/finished products. Interpretation of FTIR Spectra of Rudraksha Bead shows presence of various functional groups such as Alkane $-\mathrm{CH}_{3}-\mathrm{C}$ Methyl, $\mathrm{CH}_{3}-(\mathrm{C}=\mathrm{O}),-\mathrm{CH}_{2}-$ Methylene, $\mathrm{CH}_{2}-(\mathrm{C}=\mathrm{O}),-\mathrm{CH}_{2}-(\mathrm{C} \equiv \mathrm{N}), \stackrel{\mathrm{CH}}{ }$, Ethyl, n-propyl;

Alkene - Vinyl $-\mathrm{CH}=\mathrm{CH}_{2},>\mathrm{C}=\mathrm{CH}_{2}$

Alcohols - Secondary $\mathrm{CH}-\mathrm{OH}$

Acids - Carboxylic acids $\mathrm{COOH}$

Esters - Formates H-CO-O-R, Acetates - $\mathrm{CH}_{2}-$ $\mathrm{CO}-\mathrm{O}-\mathrm{R}$, Propionates $-\mathrm{CH}_{2}-\mathrm{CO}-\mathrm{O}-\mathrm{R}$, Butyrates an up $-\mathrm{CH}_{2}-\mathrm{CO}-\mathrm{O}-\mathrm{R}$, Acrylates $=\mathrm{CH}-\mathrm{CO}-\mathrm{O}-\mathrm{R}$, Fumarates $=\mathrm{CH}-\mathrm{CO}-\mathrm{O}-\mathrm{R}$, Maleates $=\mathrm{CH}-\mathrm{CO}-\mathrm{O}-$

R, Benzoates, phthalates $\square$-CO-O-R;

Aldehydes - Aliphatic Aldehydes $-\mathrm{CH}_{2}-\mathrm{CHO}$;

Ketones - Aliph. Ketones $\mathrm{CH}_{2}-\mathrm{CO}-\mathrm{CH}_{2}$;

Amides - $\mathrm{CO}-\mathrm{NH}_{2}$;
Anhydrides - Normal anhydrides C-CO-O-CO-

C, Cyclic anhydrides

\section{REFERENCES}

1. The translation of rudrākșa as "Rudra's Teardrops" and definition as berries of Elaeocarpus ganitrus: Stutley, p. 119.

2. Stutley, M. (1985). The Illustrated Dictionary of Hindu Iconography. New Delhi, India: Munshiram Manoharlal Publishers. ISBN 81-215-1087-2.

3. Koul, M. K. (2001-05-13). "Bond with the beads". Spectrum. India: The Tribune.

4. Lee, D. W. (1991). "Ultrastructural Basis and Function of Iridescent Blue Color of Fruits in Elaeocarpus". Nature. 349 (6306): 260-262. doi: $10.1038 / 349260 a 0$.

5. Das, Subhamoy. "The Holy Rudraksha: Super Seed".

6. For the five-division type as signifying Shiva's five faces and terminology pañcānana, see: Stutley, p. 119. 
7. Seetha, K. N. (2008). Power of Rudraksha (4th ed.). Mumbai, India: Jaico Publishing House. ISBN 978-81-7992-844-8.

8. Laatsch, M. (2010). Rudraksha. Die Perlen der shivaitischen Gebetsschnur in altertümlichen und modernen Quellen. Munich: Akademische Verlagsgemeinschaft München. ISBN 978-3-89975-411-7.

9. David W. Lee, The biology of rudraksha, Currrent Science, Vol. 75, No. 1, 1998

10. Corner, E.J.H., Wayside Trees of Malaya, Government Printing Office, Singapore, 1952, $2^{\text {nd }}$ edn.

11. Brouillard, R., Phytochemistry, 1983, 22, 1311-1323.
12. Lee, D. W., Nature, 1991, 349, 260-262.

13. Fox, D.S., Animal Structural Colors and Biochromes, University of California Press, Berkeley, 1978.

14. Lee, D. W., Am. Sci., 1997, 85, 56-63.

15. Lee, D. W. and Lowry, J.B., Nature, 1975, 254, 50-51.

16. Hebant, C. W. and Lee, D. W., Am. J. Bot., 1984, 71, 216-219.

17. Graham, R. M., Lee, D. W. and Norstog, K., Am. J. Bot., 1993, 80, 198-203.

18. Gould, K. S. and Lee, D. W., Am. J. Bot., 1986, 83, 45-50. 